九州大学学術情報リポジトリ

Kyushu University Institutional Repository

\title{
A LIST OF THE CHRYSOMELID SPECIES FROM HONG KONG, WjTH DESCRIPTIONS OF THREE NEW SPECIES
}

Kimoto, Shinsaku

https://doi.org/10.5109/2355

出版情報: ESAKIA. 6, pp. 55-63，1967-10-10. Hikosan biological laboratory，Faculty of Agriculture, Kyushu University バージョン：

権利関係 : 


\title{
A LIST OF THE CHRYSOMELID SPECIES FROM HONG KONG, WITH DESCRIPTIONS OF THREE NEW SPECIES * $†$
}

\author{
BY \\ Shinsaku Кімото
}

This paper is a result of my work on the Chrysomelid species from Hong Kong taken by the 1965 field work of the Japanese team, under the Japan-U. S. Cooperative Science Program.

In the course of this study, I am indebted to Prof. K. Yasumatsu, Prof. Y. Hirashima, Prof. T. Shirôzu and Prof. S. Miyamoto (Kyushu University), Dr. S. Asahina (National Institute of Health, Tokyo), Dr. K. Morimoto (Forest Experiment Station, Tokyo) and Mr. Y. Miyatake (Ôsaka Museum of Natural History), for their kind cooperation and encouragment.

\section{Lema coromandeliana (Fabricius)}

\section{Subfamily Criocerinae}

Lam Tsuen Valley, nr. Pak Ngau Shek (5 exs., 30. v. 1965, K. Morimoto leg.).

Ho Chung (1 ex., 22. iv. 1965, S. Miyamoto leg.; 1 ex., 31. v. 1965, K. Morimoto leg.).

Lema chujoi Gressitt \& Kimoto

Lam Tsuen Valley, nr. Pak Ngau Shek (2 exs., 30. v. 1965, S. Asahina \& K. Morimoto leg.)

\section{Lema lacosa Pic}

Lam Tsuen Valley, nr. Pak Ngau Shek (4 exs., 30. v. 1965, K. Morimoto leg.).

Lema rufotestacea Clark

Lam Tsuen Valley, nr. Pak Ngau Shek (3 exs., 30. v. 1965, K. Morimoto leg.).

Tai Po Kau (1 ex., 21. iv. 1965, T. Shirôzu leg.).

* Contribution Ser. 2, No. 39. Hikosan Biological Laboratory, Faculty of Agriculture, Kyushu University, Hikosan.

$\dagger$ Partly supported by a grant from "Japan Society for the Promotion of Science" in connection with Japan-U. S. Cooperative Science Program : Zoogeography and Ecology of Pacific Area Insects. 


\section{Subfamily Cryptocephalinae}

Cryptocephalus luteosignatus Pic

Aberdeen (3 exs., 23. iv. 1965, Y. Hirashima leg.).

Cryptocephalus trifasciatus Fabricius

Lam Tsuen Valley, nr. Pak Ngau Shek (3 exs., 30. v. 1965, K. Morimoto \& Y. Miyatake leg.).

\section{Subfamily Chlamisinae}

Chlamisius chinensis (Baly)

Lam Tsuen Valley, nr. Pak Ngau Shek (1 ex., 30. v. 1965, Y. Miyatake leg.).

Chlamisius shirozui Chû jô

Lam Tsuen Valley, nr. Pak Ngau Shek (1 ex., 30. v. 1965, Y. Miyatake leg.).

This species is here recorded from China for the first time.

\section{Subfamily Lamprosomatinae}

Oomorphoides pallidicornis Gressitt \& Kimoto

Tai Po Kau (3 exs., 29. v. 1965, K. Morimoto \& Y. Miyatake leg.; 1 ex., 21. iv. 1965, T. Shirôzu leg.).

\section{Subfamily E umolpinae}

Pagria sigcata (Motschulsky)

Lam Tsuen Valley, nr. Pak Ngau Shek (8 exs., 30. v. 1965, K. Morimoto leg.).

Abirus fortuneii (Baly)

Aberdeen (4 exs., 23. iv. 1965, Y. Hirashima leg.).

Demotina bowringii Baly

Lam Tsuen Valley, nr. Pak Ngau Shek (2 exs., 30. v. 1965, K. Morimoto leg.).

Basilepta pallidulum (Baly)

Lam Tsuen Valley, nr. Pak Ngau Shek (21 exs., 30. v. 1965, K. Morimoto \& Y. Miyatake leg.).

Tai Po Kau (2 exs., 29. v. 1965, K. Morimoto \& Y. Miyatake leg.).

Ho Chung (1 ex., 31. v. 1965, Y. Miyatake leg.).

Nodina punctostriolata (Fairmaire)

Lam Tsuen Valley, nr. Pak Ngau Shek (8 exs., 30. v. 1965, K. Morimoto \& Y. Miyatake leg.).

Tai Po Kau (13 exs., 29. v. 1965, K. Morimoto leg.). 


\section{Nodina pilifrons Chen}

Lam Tsuen Valley, nr. Pak Ngau Shek (3 exs., 30. v. 1965, K. Morimoto leg.).

Tai Po Kau (3 exs., 29. v. 1965, K. Morimoto leg.).

Ho Chung (1 ex., 31. v. 1965, Y. Miyatake leg.).

Nodina tricarinata Gressitt \& Kimoto

Lam Tsuen Valley, nr. Pak Ngau Shek (1 ex., 30. v. 1965, Y. Miyatake leg.).

Lypesthes gracilicornis (Baly)

Tai Po Kau (1 ex., 21. iv. 1965, T. Shirôzu leg.).

Colasposoma auripenne (Motschulsky)

Lam Tsuen Valley, nr. Pak Ngau Shek (1 ex., 30. v. 1965, K. Morimoto leg.).

\section{Colaspoides pilicornis Lefèvre}

Lam Tsuen Valley, nr. Pak Ngau Shek (9 exs., 30. v. 1965, K. Morimoto \& Y. Miyatake leg.).

Tai Po Kau (2 exs., 29. v. 1965, K. Morimoto \& Y. Miyatake leg.).

Ho Chung (2 exs., 31. v. 1965, Y. Miyatake leg.).

Colaspoides miyatakei n. sp. Fig. 1, c-e.

$\sigma^{7}$ : Head, pronotum and scutellum pitchy red; elytra cupreous with lateral margins metallic green ; ventral surface brownish red; legs reddish brown with tarsi yellowish; antennae yellowish brown with apical joints somewhat infuscate.

Head finely punctured, the punctures comparatively closely impressed on lower portion; vertex with a median longitudinal furrow which is interrupted at middle portion of its entire length. Antennae filiform, a little shorter than length of body; first joint thickened, second robust, glabrous, smallest, third slender, nearly three times as long as second, fourth subequal to third in length and shape, fifth longest, nearly $1 \mathrm{l} / \mathrm{Z}$ times as long as fourth, fifth to seventh subequal to each other in length and shape, eighth slightly shorter than seventh and about $5 / 6$ of length of seventh, eighth to tenth subequal to each other in length and shape, eleventh subequal to tenth in length but its apex pointed. Pronotum transverse convex side to side, about twice as wide as long, lateral margins rounded, widest at $1 / 3$ from base, strongly narrowed towards apex, and less strongly so posteriorly, anterior margin emarginate, posterior margin rounded posteriorly, surface rather closely and distinctly punctate and its interstices closely impressed with minute punctures. Scutellum nearly trapezoidal, with latero-posterior angles more or less rounded; surface smooth, shining, with some distinct punctures. Elytra elongate, somewhat narrowed posteriorly, surface convex, shining, strongly and closely punctured. Legs slender, without any spines or tufts of long hairs, first tarsal joint of anterior and middle legs widened posteriorly, 11/2 times as long as wide.

+ $:$ In most specimens, coloration of head, pronotum and scutellum darker than the male specimens and in the darkest colored specimens coloration of 
these portions becomes almost the same as elytra. First joint of anterior and middle legs subparallel-sided, more than three times as long as wide.

Length 4.5-5.0 $\mathrm{mm}$.

Holotype : Lam Tsuen Valley, nr. Pak Ngau Shek (30. v. 1967, Y. Miyatake leg.).

Paratopotypes: 3 exs., same as the holotype.

Paratype : 1 ex., same as the holotype, but K. Morimoto leg.

This new species is somewhat resembling C. diffinis Lefèvre, in general structure, but separable from this in having the anterior margin of pronotum strongly emarginate and the first joint of anterior and middle legs of male widened posteriorly.

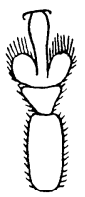

a

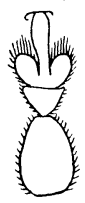

C

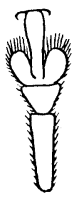

b

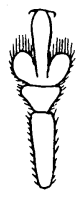

d

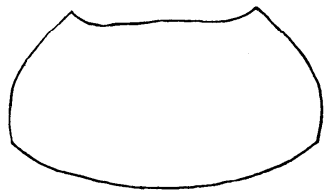

e

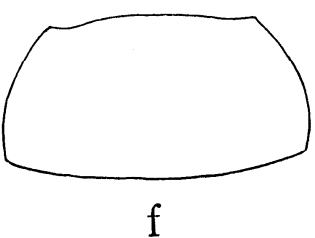

Fig. 1. a-d: Tarsi of anterior and middle legs. e-f: Prothorax. a, Colaspoides diffinis Lefèvre, $\sigma^{\top}$, b, ibid. 우; c, C. miyatakei Kimoto, n. sp., $\sigma^{7}$, d-e, ibid. ㅇ, f, C. morimotoi Kimoto, n. sp, ‥

Colaspoides morimotoi n. sp. Fig. 1, f.

Head, pronotum, scutellum and elytra metallic green to violaceous blue, in some cases with cupreous shimmer; ventral surface pitchy black; legs pitchy black with basal to median portion of femora brownish; antennae pitchy black with four or five basal joints brownish.

$\sigma^{7}$ : Head finely punctate, punctures closely impressed on lower portion, especially on clypeus; vertex with a shallow median longitudinal furrow. Antennae filiform, a little shorter than length of body; first joint thickened, second robust, glabrous, smallest, third slender, slightly longer than twice the length of second, fourth subequal to third in length and shape, fifth longest, nearly $12 / 3$ times as long as fourth, fifth to seventh subequal to each other in 
length and shape, eighth slightly shorter than seventh and about $5 / 6$ the length of seventh, eighth to tenth subequal to each other in length and shape, eleventh subequal to tenth in length but its apex pointed. Pronotum transverse, convex side to side, about twice as wide as long, lateral margins rounded, widest at $1 / 3$ from basal margin, strongly narrowed towards apex, and less strongly so posteriorly, anterior margin almost straight or slightly rounded anteriorly, posterior margin rounded posteriorly, surface not so closely but distinctly punctate and its interstices closely punctate. Scutellum semicircular, surface smooth, shining. Elytra elongate, somewhat narrowed posteriorly, surface convex, shining, strongly and closely punctured. Legs slender, without any spines or tufts of long hairs, first tarsal joint of anterior and posterior legs widened posteriorly, $11 / 2$ times as long as wide.

o : First joint of anterior and middle legs subparallel-sided, more than twice as long as wide.

Length 4.5-5.0 mm.

Holotype: Lam Tsuen Valley, nr. Pak Ngau Shek (30. v. 1965, K. Morimoto leg.).

Paratopotypes : 2 exs., same as the holotype.

Paratypes: 3 exs., same as the holotype, but Y. Miyatake leg. 8 exs., Tai Po Kau (29. v. 1965, Y. Miyatake leg.).

This new species is somewhat related to $C$. diffinis Lefèvre in general structure, but separable from this in having the first tarsal joint of anterior and middle legs of male more strongly widened posteriorly, and different coloration of legs.

\section{Subfamily Chrysomelinae}

Gonioctena (Asiphytodecta) tredecimmaculata Jacoby

Lam Tsuen Valley, nr. Pak Ngau Shek (1 ex., 30. v. 1965, K. Morimoto leg.).

Plagiodera septemvittata Stål

Lam Tsuen Valley, nr. Pak Ngau Shek (1 ex., 30. v. 1965, K. Morimoto leg.).

\section{Subfamily Galerucinae}

Oides decempunctata (Billberg)

Lam Tsuen Valley, nr. Pak Ngau Shek (5 exs., 30. v. 1965, K. Morimoto leg.).

Sinoluperus subcastatus Gressitt \& Kimoto

Lam Tsuen Valley, nr. Pak Ngau Shek (23 exs., 30. v. 1965, K. Morimoto \& S. Asahina leg.).

Tai Po Kau (19 exs., 29. v. 1965, Y. Miyatake \& K. Morimoto leg.; 1 ex., 30. v. 1965, Y. Miyatake leg.).

Ho Chung (1 ex., 31. v. 1965, K. Morimoto leg.). 
Pyrrhalta nigromarginata (Jacoby)

Tai Po Kau (4 exs., 21. iv. 1965, Y. Hirashima leg.).

Haplosomoides egena Weise

Tai Po Kau (2 exs., 29. v. 1965, 1 ex., 22. v. 1965, Y. Miyatake leg.).

Sai Kung-Tai Mong Tsai (1 ex., 22. iv. 1965, Y. Hirashima leg.).

Hoplasoma unicolor (Illiger)

Ho Chung (1 ex., 31. v. 1965, Y. Miyatake leg.).

Aulacophora palliata (Schaller)

Tai Po Kau (3 exs., 29. v. 1965, K. Morimoto \& Y. Miyatake leg.).

Aulacophora lewisii Baly

Ho Chung (1 ex., 22. iv. 1965, S. Miyamoto leg.).

Trichobalya bowringii (Baly)

Lam Tsuen Valley, nr. Pak Ngau Shek (4 exs., 30. v. 1965, K. Morimoto_\& Y. Miyatake leg.).

Tai Po Kau (1 ex., 21. iv. 1965, T. Shirozu leg.).

Micrepitrix coomani Laboissiere

Tai Po Kau (2 exs., 21. iv. 1965, S. Miyamoto leg.).

Theopea smaragdina Gressitt \& Kimoto

Ho Chung (1 ex., 31. v. 1965, Y. Miyatake leg.).

Leptarthra gebieni (Weise), New Combination

Ho Chung (1 ex., 22. iv. 1965, T. Shirozu leg.).

Gressitt \& Kimoto (1963) treated this species as a synonym of Gallerucida singularis Harold. According to my study on the type of Gallerucida gebieni Weise, preserved in Naturhistriska Riksmuseet, Stockholm, this species is not a synonym of singularis but a distinct species and to be transferred to the genus Leptarthra.

Monolepta cavipenne Baly

Tai PoKau (2 exs., 21. iv. 1965, T. Shirozu leg.; 1 ex., 29. v. 1965, K. Morimoto leg.).

\section{Monolepta signatum (Olivier)}

Ho Chung (32 exs., 31. v. 1965, K. Morimoto \& Y. Miyatake leg.; 5 exs., 22. iv. 1965, S. Miyamoto leg.).

Tai Po Kau (3 exs., 21. iv. 1965, Y. Hirashima \& S. Miyamoto leg.).

Tai Po Market (2 exs., 23. iv. 1965, T. Shirozu \& S. Miyamoto leg.). 
Monolepta palliparva Gressitt \& Kimoto

Ho Chung (1 ex., 31. v. 1965, Y. Miyatake leg.).

Tai Po Kau (1 ex., 21. iv. 1965, S. Miyamoto leg.).

Monolepia hongkongense n. sp. Fig. 2.

Yellowish brown, metathorax blackish, antennae yellowish brown with two or three apical joints infuscate; lateral half of basal margin of elytra and basal half of interior margin of elytral epipleurae blackish.

Vertex smooth, shining, impunctate ; frontal tubercles raised, distinctly separated from behind. Antennae slender, nearly equal to $2 / 3$ of body length, first long, somewhat club-shaped, second shortest, third nearly as long as or slightly longer than second and slender than second, fourth subequal to length of second and third combined, fourth and fifth subequal to each other in length and shape, sixth almost $4 / 5$ the length of fifth, sixth to tenth subequal to each other in length and shape, eleventh subequal to fifth in length but its apex pointed. Pronotum transverse, subquadrate, about $11 / 2$ times as wide as long, widest at $1 / 4$ from anterior margin, lateral margin very slightly rounded at anterior portion and slightly constricted at basal portion, anterior margin almost straight, posterior margin slightly rounded posteriorly, surface without any transverse depression, almost impunctate. Scutellum subtriangular, apex rounded, smooth, shining, impunctate. Elytra subparallel sided at basal 3/4, narrowed subapically, surface closely and distinctly punctate.

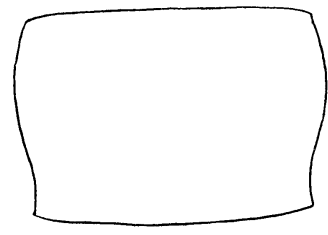

a

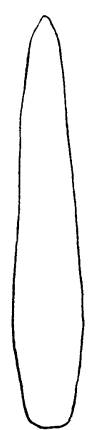

b

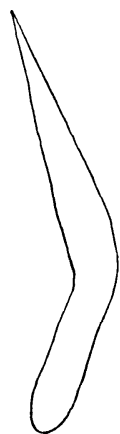

Fig. 2. Monolepta hongkongense Kimoto, n. sp. a, Prothorax, b.

Male genitalia.

Length 3.0-3.8 $\mathrm{mm}$.

Holotype : Ho Chung (31. v. 1965, Y. Miyatake leg.).

Paratypes: 2 exs., Tai Po Kau (29. v. 1965, K. Morimoto \& Y. Miyatake leg.).

This new species is closely related to M.lauta Gressitt \& Kimoto, in having pronotum subquadrate and elytra subparallel-sided, but separable in having 
metathorax, lateral half of basal margin of elytra and basal half of interior margin of elytral epipleurae blackish, and aedeagus much narrower.

M imastra cyanura (Hope)

Tai Po Kau (5 exs., 29. v. 1965, Y. Miyatake leg.).

Tai Po Market (1 ex., 23. iv. 1965, T. Shirôzu leg.).

\section{M imastra soreli Baly}

Lam Tsuen Valley, nr. Pak Ngau Shek (13 exs., 21. iv. 1965, T. Shirôzuleg.).

Sai Kung-Tai Mong Tsai (3 exs., 22. iv. 1965, T. Shirozu \& Y. Hirashima leg.).

Ho Chung (1 ex., 22. iv. 1965, S. Miyamoto leg.).

Tai Po Market (3 exs., 23. iv. 1965, T. Shirozu leg.).

\section{M imastra unicitarsis Laboissière}

Tai Po Market (1 ex., 23. iv. 1965, T. Shirozu leg.).

This specimen is distinctly different from any other known form of unicitarsis Lab., in having elytra entirely brownish. The cloration of elytra shows its resemblance to soreli Baly, but separable in having the strongly modified first tarsal joint of anterior leg.

\section{Subfamily Alticinae}

Chaetocnema (Tlanoma) discreta (Baly)

Ho Chung (3 exs., 22. iv. 1965, S. Miyamoto leg.; 5 exs., 31. v.1965, K. Morimoto leg.).

Tai Po Market (2 exs., 23. iv. 1965, S. Miyamoto leg.).

Lam Tsuen Valley, nr. Pak Ngau Shek (1 ex., 30. v. 1965, K. Morimoto leg.).

Podontia lutea (Olivier)

Lam Tsuen Valley, nr. Pak Ngau Shek (1 ex., 30. v. 1956, K. Morimoto leg.).

Tai Pau Kau (1 ex., 29 v. 1965, K. Morimoto leg.).

O phrida scaphoides (Baly)

Lam Tsuen Valley, nr. Pak Ngau Shek (1 ex., 30. v. 1956, S. Asahina leg.).

Nisotra orbiculata (Motschulsky)

Lam Tsuen Valley, nr. Pak Ngau Shek (1 ex., 30. v. 1956, S. Asahina leg.).

Neorthaea gressitti Chû jô

Lam Tsuen Valley, nr. Pak Ngau Shek (1 ex., 30. v. 1965, S. Asahina leg.).

H espera lomasa Mauilk

Tai Po Market (1 ex., 23. iv. 1965, S. Miyamoto leg.).

Tai Po Kau (1 ex., 29. v. 1965, Y. Miyatake leg.).

Lam Tsuen Valley, nr. Pak Ngau Shek (1 ex., 30. v. 1965, Y. Miyatake leg.). 
Hyphasis moseri Weise

Lam Tsuen Valley, nr. Pak Ngau Shek (1 ex., 30. v. 1965, K. Morimoto leg.).

Aphthona strigosa Baly

Ho Chung (14 exs., 31. v. 1965, Y. Miyatake \& K. Morimoto leg.).

Phyllotreta striolata (Fabricius)

Ho Chung (11 exs., 22. iv. 1965, Y. Miyatake leg.).

Aphthonomorpha collaris (Baly)

Tai Po Kau (1 ex., 21. iv. 1965, Y. Hirashima leg.).

Manobidia simplicithorax Chen

Sai Kung-Tai Mong Tsai (9 exs., 22. iv. 1965, Y. Hirashima leg.).

Lam Tsuen Valley, nr. Pak Ngau Shek (5 exs., 30. v. 1965, K. Morimoto leg.).

Aberdeen (2 exs., 23. iv. 1965, Y. Hirashima leg.).

Tai Po Kau (1 ex., 21. iv. 1965, S. Miyamoto leg.).

Ho Chung (1 ex., 31. v. 1965, Y. Miyatake leg.).

\section{Subfamily Cassidinae}

Notosacantha sinica Gresssitt

Tai Po Kau (1 ex., 29. v. 1965, K. Morimoto leg.).

Laccoptera quadrimaculata (Thunberg)

Ho Chung (1 ex., 31. v. 1965, K. Morimoto leg.).

Cassida (Taiwania) circumdata Herbst

Ho Chung (2 exs., 22. iv. 1965, S. Miyamoto leg.).

Cassida (Taiwania) obtusata Boheman

Ho Chung (1 ex., 31. v. 1965, K. Morimoto leg.). 